\title{
Weed Persistence, Crop Resistance and Phytotonic Effects of Herbicides in Maize (Zea mays) Production Under Different Weed Control Method and Poultry Manure in Kano State Nigeria
}

\author{
M. S. Garko ${ }^{1 *} \quad$ M. A. Yawale U. H. Gaya $^{1} \quad$ I. B. Mohammed ${ }^{2} \quad$ T. T. Bello ${ }^{2}$ \\ 1. Department of Crop Science Faculty of Agriculture, Kano University of Science and Technology, Wudil, \\ Kano Nigeria \\ 2. Department of Agronomy, Faculty of Agriculture Bayero University, Kano Nigeria
}

The research is financed by centre for dry land Agriculture Bayero University Kano for providing financial support and the management of Agronomy Department Bayero University, for providing technical support throughout the duration of the study (Sponsoring information).

\section{Abstract}

Results of experiment conducted during rainy season of 2016 and 2017 at teaching and research farm of Bayero university Kano, Livestock development centre Dangora with two different pre-emergence herbicides and two post-emergence herbicides all applied at two different rates, (S-Metolachlor $290 \mathrm{~g} / 1+$ Atrazine $370 \mathrm{~g} / 1 \mathrm{at} 2.0 \mathrm{~kg}$ a.i. ha ${ }^{-1}$ followed by Nicosulfuron at $100 \mathrm{~g}$ a.i.ha ${ }^{-1}$, S-Metolachlor $290 \mathrm{~g} / 1+$ Atrazine $370 \mathrm{~g} / 12.0 \mathrm{~kg}$ a.i. ha $\mathrm{h}^{-1}$ followed by Bentazone at $2.5 \mathrm{~kg}$ a.i. ha ${ }^{-1}$, Metolachlor $375 \mathrm{~g} / \mathrm{l}+$ Terbuthylazine $125 \mathrm{~g} / \mathrm{l}+$ Mesotrione $37.5 \mathrm{~g} / \mathrm{l}$ at $2.5 \mathrm{~kg}$ a.i $\mathrm{ha}^{-1}$ followed by Nicosulfuron at $100 \mathrm{~g}$ a.i. ha ${ }^{-1}$, Metolachlor $375 \mathrm{~g} / \mathrm{l}+$ Terbuthylazine $125 \mathrm{~g} / 1+$ Mesotrione $37.5 \mathrm{~g} / \mathrm{l}$ at $2.5 \mathrm{~kg}$ a.i ha ${ }^{-1}$ followed by Bentazone at $2.5 \mathrm{~kg}$ a.i. ha ${ }^{-1}$, Two hoe weeded at 3 and 6 WAS and weedy check) three levels of poultry manure $\left(0,4\right.$, and $\left.8 \mathrm{t} \mathrm{ha}^{-1}\right)$ and NPK at the rate of $120 \mathrm{~kg} \mathrm{~N}, 60 \mathrm{~kg}$ P and $60 \mathrm{~kg} \mathrm{~K} \mathrm{ha}^{-1}$ and three maize varieties (SAMMAZ 15, SAMMAZ 21 and SAMMAZ 35). The experiments was laid out in a split-split plot design with variety allocated to the main plot, poultry manure to the sub-plot and weed control method to the sub-sub plot, and was replicated three times. The result from the study showed that two hoe weeding at 3 and $6 \mathrm{WAS}$ and Application of 3Maizeforce at $2.5 \mathrm{~kg}$ a.i. ha ${ }^{-1}$ followed by Bentazone at $2.5 \mathrm{~kg}$ a.i. $\mathrm{ha}^{-1}$, significantly revealed higher crop resistance index with medium persistence index of the weeds indicating broad spectrum effect in controlling the weeds, the said treatments were best herbicides for maize production. Furthermore the said treatment is recommended for weed control that can improve maize grain yield.

Keywords: Weed Occurrence level, Weed persistence index, Crop resistance index and Phytotonic effect.

DOI: $10.7176 / \mathrm{JBAH} / 10-10-03$

Publication date:May $31^{\text {st }} 2020$

\section{Introduction}

Nigeria is a predominantly agricultural country like many developing countries. However, the main players in this sector of activity are supported by a major concern, which is the management of weeds. Indeed, these weeds are in direct competition with the cultivated plants and this causes a considerable decrease in productivity. Thus, to put in place an effective management method of weeds, one needs to have a thorough knowledge of these species, in particular their floristic composition, and their ecology.

Herbicides is chemicals used to kill or inhibit the growth of weeds and other unwanted plant pests in a particular environment where they are not wanted. There are two major types of herbicides; Species-specific herbicides are designed to kill only specific kind of plant only in an area not needed, leaving other desirable plants unharmed. Non-specific herbicides kill every plant they came in contact with. Herbicides control weeds as pre or post emergence application which drastically reduces the population of weeds resulting in higher yield of a particular crop in question, apart from harming target species they also affect the non target living organisms such as micro-flora or micro-fauna, biochemical reaction in soil and plant which may be helpful towards yield increase (Phytotonic effect) or produce detrimental effect (phytotoxic) on plant. Farmers and researches tend to ignore such activity of herbicides as it requires several attentions (Mishra, 2014). There is now, an issue of Global warming and climate change, there is need to conserve ecosystem and biodiversity along with sustained production of higher yield in crop. Waheed et al. (2008) studied pre-emergence herbicides, Metolachlor plus Atrazine, Pendimethalin and Cyanazine plus Atrazine and reported that they decreased weed population and increased grain yield over weedy control and also reported good crop resistance index in maize crop, and pointed out that grain yield of maize increased considerably under all herbicide treatments.

Chikoye et al. (2009) reported the efficiency of Atrazine in controlling weeds and thus increasing maize yield and also obtained greatest maize yield by controlling weeds with Paraquat plus Extavon and Ametryn. They further added that post-emergence herbicide application was also effective in controlling weeds with no phytotoxicity effect to the maize crop. However, Mahadi et al., (2012) in another related development at Samaru Northern Guinea savanna of Nigeria revealed that application of Atrazine + Acetochlor + Terbuthylazine at $4.0 \mathrm{~kg}$ a.i/ha 
significantly reduced weed competition with no injury, and recorded the highest growth attributed and lower shoot lodging count on quality protein Maize. In earlier development Mishra and Mishra (1997) have tried to quantify weed persistence, crop resistance and phytotonic effect of herbicidal treatments by using mathematical formula basing on growth characters where the effect of herbicide treatment can be easily identified which can give an indication basing on which further studies can be under taken for conformation. The objective of the study was to identify weeds species, phytotonic effect of herbicides on weed and maize growth and also find suitable control methods mainly to be used against these weeds to sustain maize production in the study area.

\section{Materials and method}

The experiments were conducted during the rainy seasons of 2016 and 2017 at the Research Farm of Faculty of Agriculture, Bayero University Kano (lat $11^{\circ} 58^{\prime} \mathrm{N}$, and long $8^{\circ} 26^{\prime} \mathrm{E}$ and $475 \mathrm{~m}$ above sea level) and livestock development centre, Dangora, Kiru local government area, Kano Nigeria (lat $11^{\circ} 30^{\prime} \mathrm{N}$, and long $7^{\circ} 82^{\prime}$ E and $670 \mathrm{~m}$ above sea level) while that of BUK during 2017 raining season was transferred to Doka, Tofa local area near BUK due to erosion that affect the faculty of Agriculture farm. The experiment consist of factorial combinations of six weed control methods using two pre-emergence and two post-emergence herbicides (Primextra), S-Metolachlor $290 \mathrm{~g} / 1+$ Atrazine $370 \mathrm{~g} / 1$ at $2.0 \mathrm{~kg}$ a.i. $\mathrm{ha}^{-1}$ followed by Nicosulfuron at $100 \mathrm{~g}$ a.i. ha${ }^{1}$, (Primextra), S-Metolachlor $290 \mathrm{~g} / 1+$ Atrazine $370 \mathrm{~g} / 1$ at $2.0 \mathrm{~kg}$ a.i. ha $\mathrm{ha}^{-1}$ followed by Bentazone $480 \mathrm{~g} / \mathrm{l}$ at $2.5 \mathrm{~kg}$ a.i. ha ${ }^{-1}$, (3Maizeforce), Metolachlor $375 \mathrm{~g} / 1+$ Terbuthylazine $125 \mathrm{~g} / 1+$ Mesotrione $37.5 \mathrm{~g} / 1$ at $2.5 \mathrm{~kg}^{2}$ a.i ha $\mathrm{ha}^{-1}$ followed by Nicosulfuron at $100 \mathrm{~g}$ a.i. ha-1 ${ }^{-1}$ (3Maizeforce), Metolachlor $375 \mathrm{~g} / 1+$ Terbuthylazine $125 \mathrm{~g} / \mathrm{l}+$ Mesotrione $37.5 \mathrm{~g} / \mathrm{l}$ at $2.5 \mathrm{~kg}$ a.i. ha ${ }^{-1}$ followed by Bentazone $480 \mathrm{~g} / \mathrm{l}$ at $2.5 \mathrm{~kg}$ a.i. ha ${ }^{-1}$, Two hoe weeded at 3 and 6 WAS and Weedy check, three levels of poultry manure $\left(0,4\right.$, and $\left.8 \mathrm{tha}^{-1}\right)$ and a NPK at the rate of $120 \mathrm{~kg} \mathrm{~N}, 60$ $\mathrm{kg} \mathrm{P}_{2} \mathrm{O}_{5}$ and $60 \mathrm{~kg} \mathrm{~K}_{2} \mathrm{O} \mathrm{ha}^{-1}$ and three maize varieties (SAMMAZ 15, SAMMAZ 21 and SAMMAZ 35). Poultry manure was gently incorporated two weeks before sowing while pre-emergence herbicide was applied a day after sowing and post-emergence herbicide was applied at 6 WAS. The treatments was laid out in a split-split plot design, with variety allocated to the main plot, poultry manure to the sub-plot while weed control method to the sub-sub plot, and was replicated three times.

The field was harrowed and made in to ridges; the gross plot consisted of six (6) ridges of $0.75 \mathrm{~m}$ apart of $3 \mathrm{~m}$ long $\left(13.5 \mathrm{~m}^{2}\right)$. The two (2) inner ridges were used as net plots $\left(4.5 \mathrm{~m}^{2}\right)$ while the outer row of the net plot was used for destructive and non destructive sampling purposes. Two seeds were sown at inter and intra row spacing of $75 \mathrm{~cm} \times 25 \mathrm{~cm}$ and later thinned to one plant per stand at 2 WAS. Harvesting was done by removing the cobs after they mature and de-husked manually and the cobs were sun dried and later thrashed to obtain the grains. Observations on weeds and crop were made at 12 WAS before harvest and grain yield was recorded after harvest. The various indices developed by Rana and Kumar (2014) have been used to identify the weed persistence, crop resistance and phytotonic effect due to herbicidal treatments as mentioned below.

Weed persistence index (WPI): This is the relationship between weed dry weight in control plot and that of the treatment in question as it indicating relative dry matter accumulation of weeds per count in comparison to control and was obtained using the below relation as described by Rana and Kumar (2014):

$$
\text { WPI }=\frac{\text { Weed dry weight in treated plot }}{\text { Weed dry weight in Control plot }} X \frac{\text { Weed Count in Control plot }}{\text { Weed Count in treated plot }}
$$

Crop resistance index (CRI): These data is used to determine the ability of the crop to withstand the damaging effect of the weed and was obtained from the dry weight of the plant as described by Rana and Kumar (2014):

$$
\text { CRI }=\frac{\text { Crop dry weight in treated plot }}{\text { Crop dry weight in Control plot }} X \frac{\text { Weed dry weight in Control plot }}{\text { Weed dry weight in treated plot }}
$$

Data collected were subjected to statistical analysis of variance (ANOVA) as described by Snedecor and Cochran (1994) and differences between treatment means were separated using Newman-Keuls-test (SNK) at 5\% level of probability.

\section{RESULTS AND DISCUSSION}

\section{Weed Floristic Composition and Level of Occurrence}

Table 1 presents the weed floral composition and occurrence level across the experimental sites during 2016 and 2017 rainy seasons. A total of twenty eight (28) weed species were recorded, which is made up of fifteen (15) grasses ten (10) broadleaves, and three (3) sedges. The composition of the specie indicate high occurrence with grass weeds like Rottboelia cochinchinensis (Lour), and Digitaria horizontalis (Willd.) that were closely followed by Cynodan dactylon, Imperita cylindrica (Linn.), Brachiria deflexa (Schumach.) and Pennisetum pedicellatum (Trin.) with moderate weed occurrence across all seasons and locations. However, Pennisetum violaceum (Lam.) at BUK in 2016 and Dangora in 2017 resulted in the lowest occurrence. Alamu, et al. (2018) reported that grass are the mostly spread weeds species across when integrated weed management was observed on weed population dynamic on sweet orange field.

The broad leaves weeds that recorded the highest occurrence level is Euphorbia heterophylla (L.) at Dangora 
in both seasons (51-75\%) and Phyllanthus amarus (Schum \& Thonn.) while Amaranthus spinosis (Linn.) had the lowest occurrence level across both seasons and locations. In a similar development Hyvonen and Salonen, (2002) reported that broadleaved weeds mostly observed in both season before and after herbicides were applied in another related development Chikoye et al. (2004) reported that spear grass is a noxious weed widespread in most tropical zones of the world. Highest occurrence level observed with the sedges was with Kyllinga brevifolia and Cyperus rotundus (Linn.) at BUK in 2016 and Doka in 2017, while Cyperus rotundus (Linn.) gave the least occurrence level of the sedges across both seasons and locations. The results is in accordance with the finding of Darkwa et al. (2001) worked with two grass weeds, Cyperus rotundus and Imperita cylindrica and find that they reduced performance of the crops by completion for soil resources and significantly reduced potential yield of maize.

\section{Weed persistence index (WPI)}

Weed persistence index indicating relative dry matter accumulation of weeds per count in comparison to the control plots (Table 2) the results showed that two hoe weeding at 3 and 6WAS recorded the higher persistence index across all years and locations that was closely followed by S-Metolachlor $290 \mathrm{~g} / \mathrm{l}+$ Atrazine $370 \mathrm{~g} / \mathrm{l}$ at 2.0 $\mathrm{kg}$ a.i. ha ${ }^{-1}$ followed by Nicosulfuron $100 \mathrm{~g}$ a. i. ha- ${ }^{-1}$ and S-Metolachlor $290 \mathrm{~g} / \mathrm{l}+$ Atrazine $370 \mathrm{~g} / 12.0 \mathrm{~kg}$ a.i. ha ${ }^{-1}$ followed by Bentazone $2.5 \mathrm{~kg}$ a.i. ha ${ }^{-1}$ indicating resistance of escaped weeds to control measures whereas Metolachlor $375 \mathrm{~g} / \mathrm{l}+$ Terbuthylazine $125 \mathrm{~g} / \mathrm{l}+$ Mesotrione $37.5 \mathrm{~g} / \mathrm{at} 2.5 \mathrm{~kg}$ a.i ha ${ }^{-1}$ followed by Nicosulfuron 100 $\mathrm{g}$ a i. ha ${ }^{-1}$ and Metolachlor $375 \mathrm{~g} / 1+$ Terbuthylazine $125 \mathrm{~g} / 1+$ Mesotrione $37.5 \mathrm{~g} / \mathrm{at} 2.5 \mathrm{~kg}$ a.i. ha ${ }^{-1}$ followed by Bentazone at $2.5 \mathrm{~kg}$ a.i. $\mathrm{ha}^{-1}$ ] have recorded lower persistence of escaped weeds across all years and locations showing broad spectrum effect in controlling weeds. The finding corroborate with that of Mishra et al., (2016) pointed out that weed persistence index was maximum in Hand weeding treatment and or followed by combination of Cyhalofopbutyl and Pyrazosulfuron in rice production under direct seeding.

\section{Crop resistance index (CRI)}

The crop resistance index (Table 2) indicating increased vigour of crop plant due to weed control measures indicated the least weed species and higher crop resistance obtained in plots treated with Metolachlor $375 \mathrm{~g} / 1+$ Terbuthylazine $125 \mathrm{~g} / \mathrm{l}+$ Mesotrione $37.5 \mathrm{~g} / \mathrm{l}$ at $2.5 \mathrm{~kg}$ a.i. ha ${ }^{-1}$ followed by Bentazone at $2.5 \mathrm{~kg}$ a.i. ha ${ }^{-1}$, Metolachlor $375 \mathrm{~g} / 1+$ Terbuthylazine $125 \mathrm{~g} / 1+$ Mesotrione $37.5 \mathrm{~g} / \mathrm{l}$ at $2.5 \mathrm{~kg}$ a.i. $\mathrm{ha}^{-1}$ followed by Nicosulfuron at $0.1 \mathrm{~kg}$ a.i. ha ${ }^{-1}$ and two hoe weeding at 3 and 6 WAS indicating much less harmful effect of herbicides on crop as compared to other treatments. Weedy check control recorded the lowest value of CRI indicating highest harmful effect on crop. In a similar development Ishaya, et al. (2008) pointed out that, weeds in greater densities are serious challenges to the growth and development of crop plants. The result also corroborate with the finding of Mahadi (2011) who reported that, weedy check treatments had significantly higher weed count, weed cover score, and weed dry weight than herbicide treated plots and two weeding at 3 and 6 WAS in Northern Guinea savanna of Nigeria.

\section{Grain Yield (kg ha $\left.{ }^{-1}\right)$}

Grain yield was significantly affected by pre and post-emergence herbicides in both years and locations (Table 2). In 2016, Metolachlor $375 \mathrm{~g} / 1+$ Terbuthylazine $125 \mathrm{~g} / 1+$ Mesotrione $37.5 \mathrm{~g} / \mathrm{at} 2.5 \mathrm{~kg}$ a.i ha ${ }^{-1}$ followed by Bentazone at $2.5 \mathrm{~kg}$ a.i.ha ${ }^{-1}$, Two hoe weeded at 3 and 6 WAS across both locations and with Metolachlor $375 \mathrm{~g} / 1+$ Terbuthylazine $125 \mathrm{~g} / 1+$ Mesotrione $37.5 \mathrm{~g} / \mathrm{l}$ at $2.5 \mathrm{~kg}$ a.i ha ${ }^{-1}$ followed by Nicosulfuron $100 \mathrm{~g}$ a.i. ha ${ }^{-1}$ at BUK location only produced significantly the highest maize yield which was not comparable to all other treatments and weedy check produced significantly the lowest grain yield across all seasons. Ishaya, (2004) and Mahadi, (2011) reported cereals grain yields increases because the crop was free from weeds during its critical period of weeds interference, adding that good weed control allowed greater efficiency in the use of available growth factors. However, in 2017, Two hoe weeded at 3 and 6 WAS and Metolachlor $375 \mathrm{~g} / 1$ + Terbuthylazine $125 \mathrm{~g} / 1+$ Mesotrione $37.5 \mathrm{~g} /$ at $2.5 \mathrm{~kg}$ a.i ha ${ }^{-1}$ followed by Bentazone at $2.5 \mathrm{~kg}$ a.i.ha $\mathrm{g}^{-1}$, produced significantly, the highest yield but comparable with Mesotrione $37.5 \mathrm{~g} / 2.5 \mathrm{~kg}$ a.i ha ${ }^{-1}$ followed by Nicosulfuron $100 \mathrm{~g}$ a.i. ha ${ }^{-1}$ as compared with other herbicide treatments except weedy check which produced significantly, the lowest grain yield across all locations (Table 2).

Metolachlor $375 \mathrm{~g} / 1+$ Terbuthylazine $125 \mathrm{~g} / \mathrm{l}+$ Mesotrione $37.5 \mathrm{~g} /$ at $2.5 \mathrm{~kg}$ a.i ha ${ }^{-1}$ followed by Bentazone at $2.5 \mathrm{~kg}$ a.i. $\mathrm{ha}^{-1}$ and Two hoe weeded at 3 and 6 WAS respectively produced significantly, the highest yield; although, not significantly different from Mesotrione $37.5 \mathrm{~g} / 2.5 \mathrm{~kg}$ a.i ha ${ }^{-1}$ followed by Nicosulfuron $100 \mathrm{~g}$ a.i. ha ${ }^{1}$ herbicide treatments in both seasons, probably due to the low phytotoxicity of the herbicide combinations and its ability to control weeds effectively throughout the season, which prevented weed competition. The significantly higher yields produced by the fore mentioned herbicides at the stated respective rates could be due to their little or no phytotoxic effect on maize, coupled with its high selectivity to weeds. This resulted in better uptake of plant nutrients and moisture which resulted in better growth and higher yield. This is similar to the findings of Grichar 
et al. (2001) who reported that Metolachlor at $3.36 \mathrm{~kg}$ a.i./ha increased yield of sesame up to $80 \%$ over the untreated check, and further found that, Diuron at 1.5 to $2.5 \mathrm{~kg}$ a.i./ha and Pendimethalin at 1.0 to $2.5 \mathrm{~kg}$ a.i./ha produced significantly low yields due to their phytotoxic effect on the crop.

Application of NPK fertilizer and $8 \mathrm{t} \mathrm{ha}^{-1}$ poultry manure had resulted in the highest grain yield than all other treatments in both seasons and locations. This was followed by grain yield from application of $4 \mathrm{tha}^{-1}$ poultry manure while the zero poultry manure plots consistently recorded the lowest grain yield across both seasons and locations. The results is consonance with that of Mahadi et al. (2013) who pointed out that poultry manure provides an excellent source of organic matter, restoring some organic matter depleted by many agricultural activities as well as improving the structure of the soil, and also Ibeawuchi et al. (2007) reported that higher levels of manure increases the water soluble and exchangeable potassium and magnesium which enhance dry matter production and grain yield of the crop.

The varietal differences were only significant in 2016 at Dangora in which SAMMAZ 21 and SAMMAZ 35 statistically recording higher grain yield compared with the SAMMAZ 15. Similar findings were reported by Sani et al. (2015) that, varieties of maize differ in their potential productivity. The ability of SAMMAZ 21 and 35 to efficiently smother and intercept more solar radiation might have led to its higher production of grain yield. A similar result was observed by Chikoye et al. (2009) who noted that, short-cycle maize had the lowest weeds densities but produced acceptable yield only in low stress environment. They further stated that, long-cycle varieties are too susceptible to weed infestation especially Striga and are not completely adapted to agro-ecological conditions of the study area.

The interaction between poultry manure and weed control method on grain yield of maize in 2016 rainy season at both locations is presented in Table 3. The results showed that, statistically highest grain yield was recorded with two hoe weeding at 3 and 6 WAS, combined with NPK fertilizer than all other treatments but was comparable or with $8 \mathrm{tha}^{-1}$ of poultry manure and two hoe weeding at 3 and $6 \mathrm{WAS}$, NPK and $8 \mathrm{tha}^{-1}$ of poultry manure combined with Metolachlor $375 \mathrm{~g} / 1+$ Terbuthylazine $125 \mathrm{~g} / 1+$ Mesotrione $37.5 \mathrm{~g} / 1$ at $2.5 \mathrm{~kg}$ a.i. hafollowed by Bentazone at $2.5 \mathrm{~kg}$ a.i. ha ${ }^{-1}$ while least grain yield was obtained from weedy check combined with zero poultry manure across both locations.

At Dangora during 2017rainy season, higher grain yields were obtained from application of NPK fertilizer combined with the two hoe weeding at 3 and 6 WAS that were statistically similar when $8 \mathrm{t} \mathrm{ha}^{-1}$ poultry manure was combined with the Metolachlor $375 \mathrm{~g} / 1+$ Terbuthylazine $125 \mathrm{~g} / 1+$ Mesotrione $37.5 \mathrm{~g} / 1$ at $2.5 \mathrm{~kg}$ a.i. ha ${ }^{-1}$ followed by Bentazone at $2.5 \mathrm{~kg}$ a.i. ha ${ }^{-1}$ or two hoe weeding at 3 and 6 WAS while weedy check along with no poultry manure recorded the least grain yield (Table 3 ). This indicate the effectiveness of those combinations in destroying weeds without injuring the crop and the roles played by poultry manure for releasing nutrients which mineralized rapidly for protein synthesis and utilization of carbohydrates for cell and enzymes development that further resulted in better maize establishment and performance, as evidence by good crop resistance, higher chlorophyll content and heavier dry weight plants observed in this study.

A similar development was obtained by Chikoye et al. (2009) who reported the efficiency of Atrazine in controlling weeds and thus increasing maize growth and also obtained greatest maize dry weight by controlling weeds with Paraquat plus Extavon and Ametryn. The result is in harmony with that of Ibeawuchi et al. (2007) who reported that, $8 \mathrm{tha}^{-1}$ poultry manure resulted in significantly increase in maize performance and yield. In a related development by Sharifai et al. (2012) they pointed out that, the principal nutrient in poultry manure such as N, P and $\mathrm{K}$ is associated with vigour growth and dark green color of leaves as a result of significant role it plays in photosynthesis which leads to increases in the production of higher chlorophyll, LAI and taller plants.

The results observed in weedy check may be attributed to higher number of weeds in plots which correspondingly drew a wider range of nutrients from the crop and weeds as evidence by lower crop resistance and lower dry weight production of the plants that was observed in zero poultry manure combined with weedy check plots. This result revealed that higher weed persistence index demonstrated the high weed dry weighting ability of the treatment.

\section{Conclusion}

Herbicides are available that can help control weeds during the production of maize. Control of weeds is the most important part of maize production. There are many hundreds or thousands hectares of maize to be grown every year which will give good economic return. However, improved weed control systems will contribute to increased grain yield. The strategy that is being considered is to use a pre-emergence herbicide that has residual control and will provide effective soil residual control for approximately 4 to 6 weeks followed by a post-emergence herbicide that will control weeds and possibly provide residual control of weeds that have not germinated. Furthermore, two hoe weeding at 3 and 6WAS and Metolachlor $375 \mathrm{~g} / 1+$ Terbuthylazine $125 \mathrm{~g} / 1+$ Mesotrione $37.5 \mathrm{~g} / 1$ at $2.5 \mathrm{~kg}$ a.i. $\mathrm{ha}^{-1}$ followed by Bentazone at $2.5 \mathrm{~kg}$ a.i. ha ${ }^{-1}$ has maximum phytotonic effect than other herbicides combinations. Two hoe weeding at 3 and 6WAS treatment has maximum tendency of weed persistence index followed by plots treated with Metolachlor $375 \mathrm{~g} / 1+$ Terbuthylazine $125 \mathrm{~g} / \mathrm{l}+$ Mesotrione $37.5 \mathrm{~g} / \mathrm{l}$ at $2.5 \mathrm{~kg}$ a.i. ha ${ }^{-1}$ followed by 
Bentazone at $2.5 \mathrm{~kg}$ a.i. ha ${ }^{-1}$ whereas weedy check have lowest values. The said treatments combinations were best herbicides for maize production.

\section{References}

Alamu O. O. Tijani-Eniola H., Olaniyan, A. A and Olaniyi O.W. (2018). Influence of Integrated Weed Management on Weed Population Dynamics, Growth and Yield of Sweet Orange (Citrus sinensis) in derived savanna. Nigerian Journal of Weed Science. Vol. 31. Pp 28-43.

Darkwa, E. O., Johnston, B. K., Nyalemegme, K., Yangyuoru, M., Boateng, C. and Terry, P. J. (2001). Weed management on Vertisols for small-scale farmers in Ghana, International Journal of Pest Management Vol. 47 (4): 299-303.

Chikoye, D., Schulz S. and Ekeleme, F. (2004). Evaluation of integrated weed management practice for maize in the northern Guinea savanna of Nigeria. Crop Protection 23: Pp 895-900

Chikoye, D., Lum, A. F., Ekeleme, F. and Udensi, U. E. (2009). Weed control in Maize in Nigeria International Journal of Pest Management, Volume 55.

Grichar, W. J., Brent, A. B. and Kevin, D. B. (2004). Effect of row spacing and herbicide dose on weed control and grain sorghum yield. Crop protection 23: 263-267.

Hyvonen T. and Salonen J, (2002) Weed Species Diversity and Community Composition in Cropping Practices of two intensity levels -a six Experiment Journal of Plant Ecology. 159 Pp 73-81.

Ibeawuchi, I. I., Opara, F. A., Tom, C. T. and Obiefuna J. C (2007). Graded Replacement of Inorganic with Organic Manure for Sustainable Maize Production in Owerri Imo State, Nigeria. Life Science Journal 4:(2): ISSN 1097- 8135, 82-87.

Ishaya, D. B., Tunku P., and N. C. Kuchinda. (2008). Evaluation of some weed control treatments for long season weed control in maize under zero and minimum tillage at Samaru in Nigeria. Crop Protection. 27: 1047-1051.

Mahadi, M. A (2011). Effects of Weed Control Methods and Cow Dung Manure on the Performance of Quality Protein Maize (Zea mays L.) in the Northern Guinea Savanna Zone of Nigeria. Ph.D. Thesis, Department of Agronomy, Ahmadu Bello University Zaria, Nigeria. 102 109pp.

Mahadi, M. A, Dadari S. A, Tanimu B, Kuchinda N. C, Sharifai A. I. and Bature M. S. (2013). Effects of Weed Control and Cow Dung Manure on Growth Performance of Quality Protein Maize in Samaru, Zaria, Nigeria. Nigerian Journal of Basic Applied Science. 21:85-95.

Mishra M. (2014). Diagnosis of crop reaction to management. Agronomy Activities at Glance 4(1): 38.

Mishra, M., Dash R. and Mishra M. (2016). Weed persistence, crop resistance and phytotonic effects of herbicides indirect-seeded rice. Indian Journal of Weed Science 48(1): 13-16, 20.

Rana, S., and Kumar, S. (2014). Research Techniques in Agronomy Department of Agronomy, College of Agriculture, CSK Himachal Pradesh Krishi Vishvavidyalaya, Palampur, 39 - 40.

Sani, B. M., Abubakar I. U., Falaki A. M., Mani H. and Jaliya M. M. (2015). Grain Yield and Yield Components of Quality Protein Maize Genotypes as Influenced by Irrigation and Plant Population in the Nigerian Savannah. Journal of Agricultural Science; Vol. (6), No. 4; 2014 ISSN 1916-9752 E-ISSN.

Snedecor, G. W. and Cochran, W. G. (1994). Statistical Methods. Sixth edition; Iowa University press, Iowa, USA. 607. 
Table 1: Weed Species, Family, Life cycle, Morphology and their Level of Occurrence at BUK, Dangora and Doka, 2016 and 2017 Rainy Seasons.

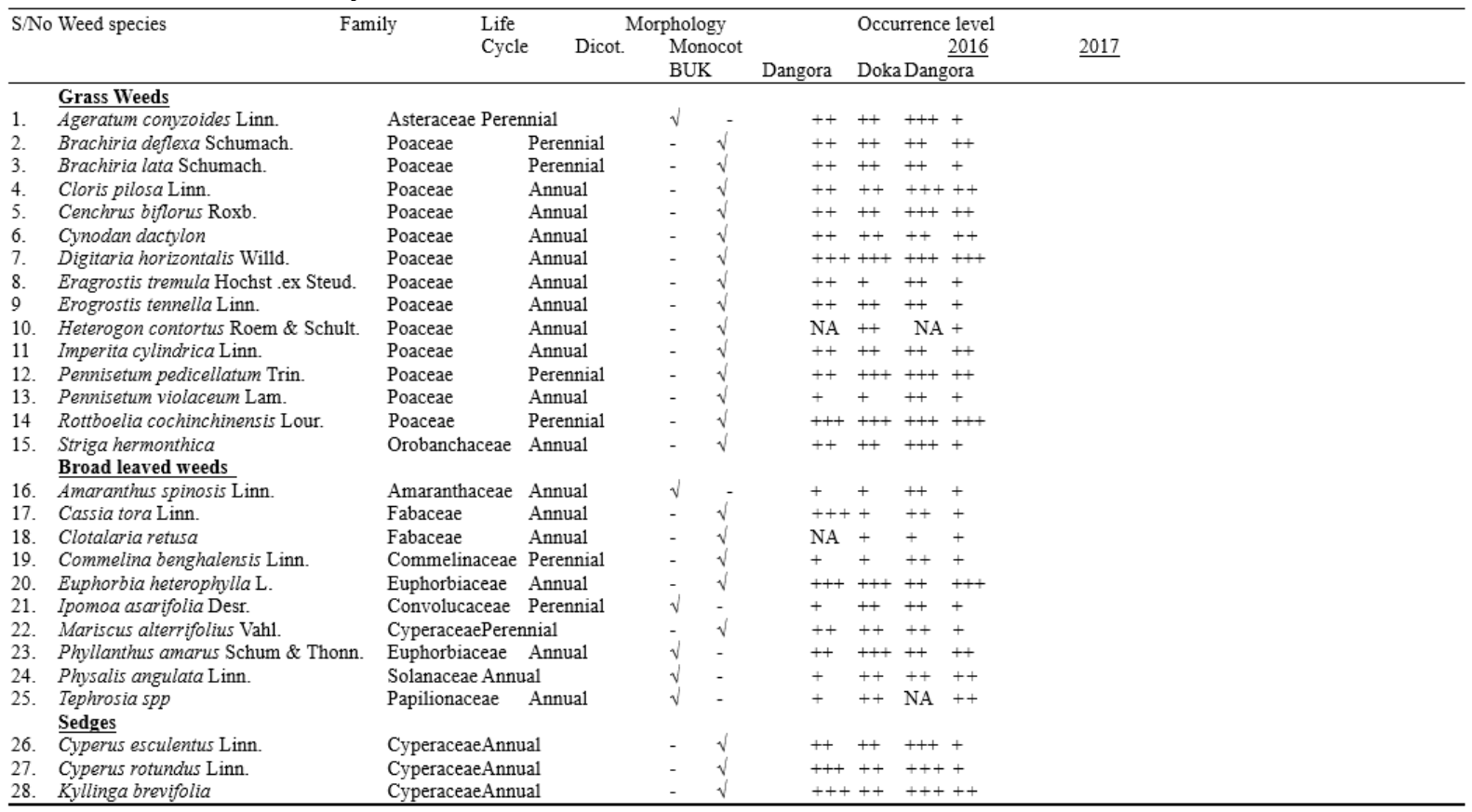

$\sqrt{ }=$ presence,$-=$ Absence,$+=$ low weed specie occurrence, $++=$ moderate weed specie occurrence and $+++=$ High weed species occurrence NA= Not available.

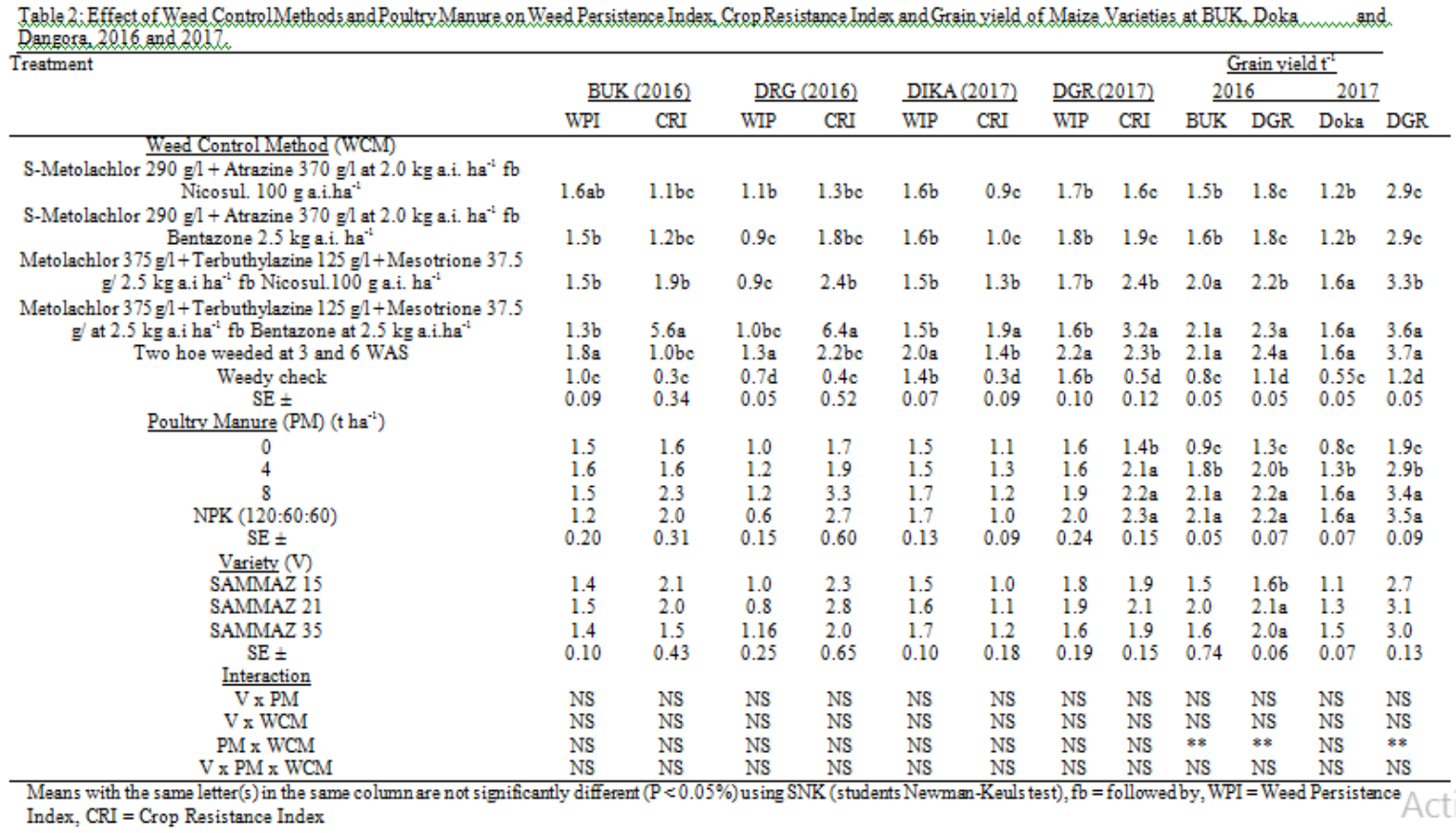


Table 3: Interaction between Poultry Manure and Weed Control Method on Grain Yield at BUK and Dangora 2016 and 2017 Rainy Seasons.

\begin{tabular}{|c|c|c|c|c|c|c|}
\hline \multirow[t]{2}{*}{ Poultry Manure $(\mathrm{M})\left(\mathrm{t} \mathrm{ha}^{-1}\right)$} & \multicolumn{6}{|c|}{$\underline{\text { Weed Control Methods (WCM) }}$} \\
\hline & T1 & $\mathrm{T} 2$ & $\mathrm{~T} 3$ & $\mathrm{~T} 4$ & T5 & T6 \\
\hline & \multicolumn{6}{|c|}{ At BUK 2016 Grain Yield } \\
\hline 0 & $0.85 \mathrm{ij}$ & $0.90 \mathrm{ij}$ & $0.95 \mathrm{ij}$ & $1.09 \mathrm{i}$ & $1.06 \mathrm{ij}$ & $0.49 \mathrm{k}$ \\
\hline 4 & $1.54 \mathrm{~h}$ & $1.63 \mathrm{gh}$ & $2.19 \mathrm{de}$ & $2.24 \mathrm{cde}$ & $2.19 \mathrm{de}$ & $0.84 \mathrm{ij}$ \\
\hline 8 & $1.90 \mathrm{fg}$ & $1.98 \mathrm{ef}$ & $2.45 \mathrm{bcd}$ & $2.55 \mathrm{ab}$ & $2.54 \mathrm{ab}$ & $0.90 \mathrm{ij}$ \\
\hline NPK $(120: 60: 60)$ & $1.84 \mathrm{fg}$ & $2.01 \mathrm{ef}$ & $2.49 \mathrm{bc}$ & $2.56 \mathrm{ab}$ & $2.77 \mathrm{a}$ & $0.80 \mathrm{j}$ \\
\hline \multirow{2}{*}{$\mathrm{SE} \pm$} & 0.098 & & & & & \\
\hline & \multicolumn{6}{|c|}{ At DGR 2016 Grain Yield } \\
\hline 0 & 1.191 & $1.21 \mathrm{k}$ & $1.38 \mathrm{ij}$ & $1.48 \mathrm{j}$ & $1.33 \mathrm{ijk}$ & $0.87 \mathrm{~m}$ \\
\hline 4 & $1.88 \mathrm{~h}$ & $1.91 \mathrm{gh}$ & $2.33 \mathrm{de}$ & $2.27 \mathrm{ef}$ & $2.48 \mathrm{bcd}$ & $1.20 \mathrm{jk} 1$ \\
\hline 8 & $2.05 \mathrm{gh}$ & $2.10 \mathrm{fg}$ & $2.49 \mathrm{~cd}$ & $2.66 \mathrm{ab}$ & $2.78 \mathrm{a}$ & $1.25 \mathrm{jk} 1$ \\
\hline NPK $(120: 60: 60)$ & $2.02 \mathrm{gh}$ & $2.06 \mathrm{gh}$ & $2.57 \mathrm{bc}$ & $2.74 \mathrm{a}$ & $2.79 \mathrm{a}$ & $1.46 \mathrm{kl}$ \\
\hline \multirow{2}{*}{$\mathrm{SE} \pm$} & 0.071 & & & & & \\
\hline & \multicolumn{6}{|c|}{ At DGR 2017 Grain Yield } \\
\hline 0 & 1.680 & $1.67 \mathrm{o}$ & $2.10 \mathrm{n}$ & $2.401 \mathrm{~m}$ & $2.38 \mathrm{~m}$ & $0.97 \mathrm{q}$ \\
\hline 4 & $2.85 \mathrm{k}$ & $2.76 \mathrm{kl}$ & $3.25 \mathrm{hj}$ & $3.56 \mathrm{f}-\mathrm{j}$ & $3.74 \mathrm{efg}$ & $1.17 \mathrm{pq}$ \\
\hline 8 & $3.28 \mathrm{hij}$ & $3.53 \mathrm{~g}-\mathrm{j}$ & $3.85 \mathrm{def}$ & $4.12 \mathrm{bcd}$ & $4.28 \mathrm{abc}$ & $1.34 \mathrm{op}$ \\
\hline NPK $(120: 60: 60)$ & $3.53 \mathrm{f}-\mathrm{j}$ & $3.57 \mathrm{fgh}$ & $3.9 \mathrm{cde}$ & $4.29 \mathrm{ab}$ & $4.51 \mathrm{a}$ & $1.25 \mathrm{pq}$ \\
\hline $\mathrm{SE} \pm$ & 0.130 & & & & & \\
\hline
\end{tabular}

